\title{
Letter of Authorization
}

National Cancer Institute

\section{Source}

National Cancer Institute. Letter of Authorization. NCI Thesaurus. Code C79189.

Notification from the proper authority endorsing an activity. 